\title{
Diel periodicities in cell characteristics of the surfzone diatom Anaulus birostratus: their role in the dynamics of cell patches
}

\author{
M. M. B. Talbot \& G. C. Bate \\ Department of Botany, Institute for Coastal Research, University of Port Elizabeth, P.O. Box 1600, Port Elizabeth, South Africa
}

\begin{abstract}
Characteristics of the surf diatom Anaulus birostratus have been recorded over two $28 \mathrm{~h}$ studies in an effort to understand the factors responsible for the formation and decay of cell patches in the surfzone. A sequence of anatomical and morphological changes characterising the process of asexual reproduction were observed in field samples. Division frequency, cell dimensions and cell condition all exhibited diel periodicities which were synchronized with observed variations in cell concentration within the inner surfzone. Cell division was restricted largely to early morning. Initiated just before dawn, it reached a maximum frequency of $53 \%$ at $0830 \mathrm{~h}$ and ceased by $1900 \mathrm{~h}$. The first appearance of recently divided cells lagged behind cell division by approximately $3 \mathrm{~h}$ and coincided with the exponential increase in cell numbers in the inner surfzone. Changes have been observed in the outer appearance of cell frustules, which were smooth-walled during the period of maximum division. During the late afternoon when division frequency was less than $5 \%$, more than $30 \%$ of all cell margins appeared irregular. There was a strong diel periodicity in the dimension of the pervalvar axis which increased by $52 \%$ between 0300 and $0800 \mathrm{~h}$; this increase was in phase with cell division. The formation of cell patches does not constitute a blooming phenomenon, but is, rather, the result of an advection process which appears to be controlled by or linked to the process of asexual reproduction.
\end{abstract}

\section{INTRODUCTION}

The surf diatom Anaulus birostratus (Grunow) Grunow (Bacillariophyceae) is the dominant phytoplankton species along the $45 \mathrm{~km}$ stretch of sandy beach that forms the NE sector of Algoa Bay, South Africa (Sloff et al. 1984). Apart from the importance of this species as a major primary producer within the surfzone ecosystem (Campbell et al. 1985), its most striking feature is the intense temporal variability shown in cell numbers; Sloff (1984) and Sloff et al. (1984) reported both a diel and a day-to-day variability within the inner surfzone at the Sundays River Beach. Maximum development of cell patches of $A$. birostratus occurs around midday, when cell concentrations often exceed $10^{6}$ cells $\mathrm{ml}^{-1}$. Originally reported by McLachlan \& Lewin (1981), these diurnal patches were referred to as 'blooms' in accordance with the terminology employed in other reports of high monospecific accumulations of surf diatoms in other parts of the world (Cassie \& Cassie 1960, Gunter \& Lyles 1979,
Garver \& Lewin 1981). In a more thorough assessment of the spatio-temporal distribution of $A$. birostratus in the surfzone, Sloff et al. (1984) hypothesised that the high cell concentrations were the result of cell accumulations by hydrographic forces, rather than through cell division (blooming).

The mechanisms responsible for the formation of surfzone patches have yet to be elucidated. It has been assumed that the 'seeding' or inoculation of the inner surfzone accurs from an offshore stock of cells (Lewin \& Hruby 1973, Winter 1983). Once within the inner surfzone, surf diatoms achieve dominance over other less abundant species and the cell numbers increase to well above those seaward of the surfzone. The appearance and disappearance of Chaetoceros armatum patches along the Washington coast, USA, is thought to operate through some floatation mechanism. During daylight hours the cells float to the surface, creating locally high concentrations visible to the eye as a 'bloom' (Lewin \& Hruby 1973). A redistribution of cells throughout the water column is thought to be respon- 
sible for the patch disappearance. In the case of Anaulus birostratus, patch rhythmicity has been linked to the movement of cells into and out of the inner surfzone (Sloff et al. 1984). A similar view was held by Kindley (1983). High concentrations of the surf diatom C. armatum behind the breaker line of high-energy sandy beaches were expected to play a role in the formation of diatom patches in the inner surfzone.

These hypotheses have remained largely untested due to a paucity of work on the behavioural characteristics and life cycle of surfzone diatoms, particularly with respect to diel periodicities. Lewin \& Rao (1975) found a strong diel periodicity in the division activity of Chaetoceros armatum. Working on the same species, Lewin \& Hruby (1973) deduced, from rapid diel changes in the vertical distribution of C. armatum, that cells experience a diel rhythm in density. There is no data on physiological or anatomical changes in Anaulus birostratus or any other member of this genus (Drebes \& Schulz 1981).

In contrast to surf diatoms, the life cycle events of species that bloom in offshore waters have received much attention. The comprehensive reviews of Sournia (1974) and Smetacek (1985) stress the intimate relation between the formation and decay of blooms and changes in the physiology and morphology of the phytoplankton. Anderson et al. (1973) concluded from their study on Gonyaulax tamarensis Lebour that 'The life cycle of this motile organism is extremely important in the bloom dynamics:

The aim of the present study was to investigate diel changes that may take place in the division activity, condition or dimensions of Anaulus birostratus cells with the view of providing some understanding of the mechanisms responsible for its appearance in the inner surfzone during the early morning and its subsequent disappearance in the afternoon. The work presented here forms part of a comprehensive ecological study of the $A$. birostratus population.

\section{MATERIALS AND METHODS}

Water samples were collected from the inner surfzone (i.e. between the shoreline and $1.5 \mathrm{~m}$ depth) at the Sundays River Beach, Algoa Bay $\left(33^{\circ} 43^{\prime} \mathrm{S}\right.$; $25^{\circ} 52^{\prime} \mathrm{E}$ ), during two $28 \mathrm{~h}$ studies (January and April 1985). This exposed beach has a semi-diurnal tide with a mean spring amplitude of $1.6 \mathrm{~m}$. Despite the tidal range, the beach is best classified as low mesotidal according to the classification of Hayes (1979), since it is wave dominated (wave height at breaker is 1 to $3 \mathrm{~m}$ ). The beach is composed of fine to medium quartz grains (McLachlan et al. 1984).

Both exercises were carried out under light and variable winds (10 knots) and accompanied by a medium to low energy condition (wave height between $1 \mathrm{~m}$ and $1.5 \mathrm{~m}$ in January and $0.5 \mathrm{~m}$ to $1 \mathrm{~m}$ in April). The beach was in a transverse bar-rip configuration according to the beach morphodynamic classification of Wright \& Short (1983). The system was attended by an incipient outer bar where an infrequent wave-break occurred. Sea temperature was $21^{\circ} \mathrm{C}$ in January and $18^{\circ} \mathrm{C}$ in April. The January and April light regimes are presented in Table 1 together with the times of low and high tide. Intensive measurements of photosynthetic photon flux density (PPFD) were made with an integrating spherical quantum sensor LI193SB (LI-COR Inc.).

Depth-integrated samples were collected from 6 sites $50 \mathrm{~m}$ apart, by driving a $1 \mathrm{~m} \times 46 \mathrm{~mm}$ (ID) PVC pipe throughout the entire water column. This was done in order to overcome the marked depth stratification of cells within this region (Sloff et al. 1984). All samples were immediately preserved in $1 \%$ Lugol's solution (Saraceni \& Ruggiu 1974). Aliquots of the preserved samples (25 to $100 \mathrm{ml}$ ) were settled according to the Utermöhl settling technique (Utermöhl 1958). Anaulus birostratus cells were enumerated and photographed at $200 \times$ or $400 \times$ magnification using an inverted microscope (Invertoscope D, Zeiss, West Germany). The cell parameters recorded included cell length (apical axis) and cell breadth (pervalvar axis) (Fig. 1A), frustule condition (smooth-walled, irregular or 'indistinguishable') and state of asexual division (resting, dividing or recently divided). A detailed description of the criteria used for distinguishing the various division stages is given below (see 'Results') Terminology follows the recommendations of Anonymous (1975).

Table 1. Light and tide times for the January and April exercises

\begin{tabular}{|ccccccc|}
\hline Month & First light & Last light & Sunrise & Sunset & Low tide & High tide \\
\hline Jan & $0445 \mathrm{~h}$ & $2058 \mathrm{~h}$ & $0541 \mathrm{~h}$ & $2020 \mathrm{~h}$ & $0054 \mathrm{~h}$ & $0721 \mathrm{~h}$ \\
$\mathrm{Apr}$ & $0555 \mathrm{~h}$ & $1930 \mathrm{~h}$ & $0653 \mathrm{~h}$ & $1830 \mathrm{~h}$ & $0741 \mathrm{~h}$ & $1928 \mathrm{~h}$ \\
& & & & $1954 \mathrm{~h}$ & $1347 \mathrm{~h}$ \\
\hline
\end{tabular}



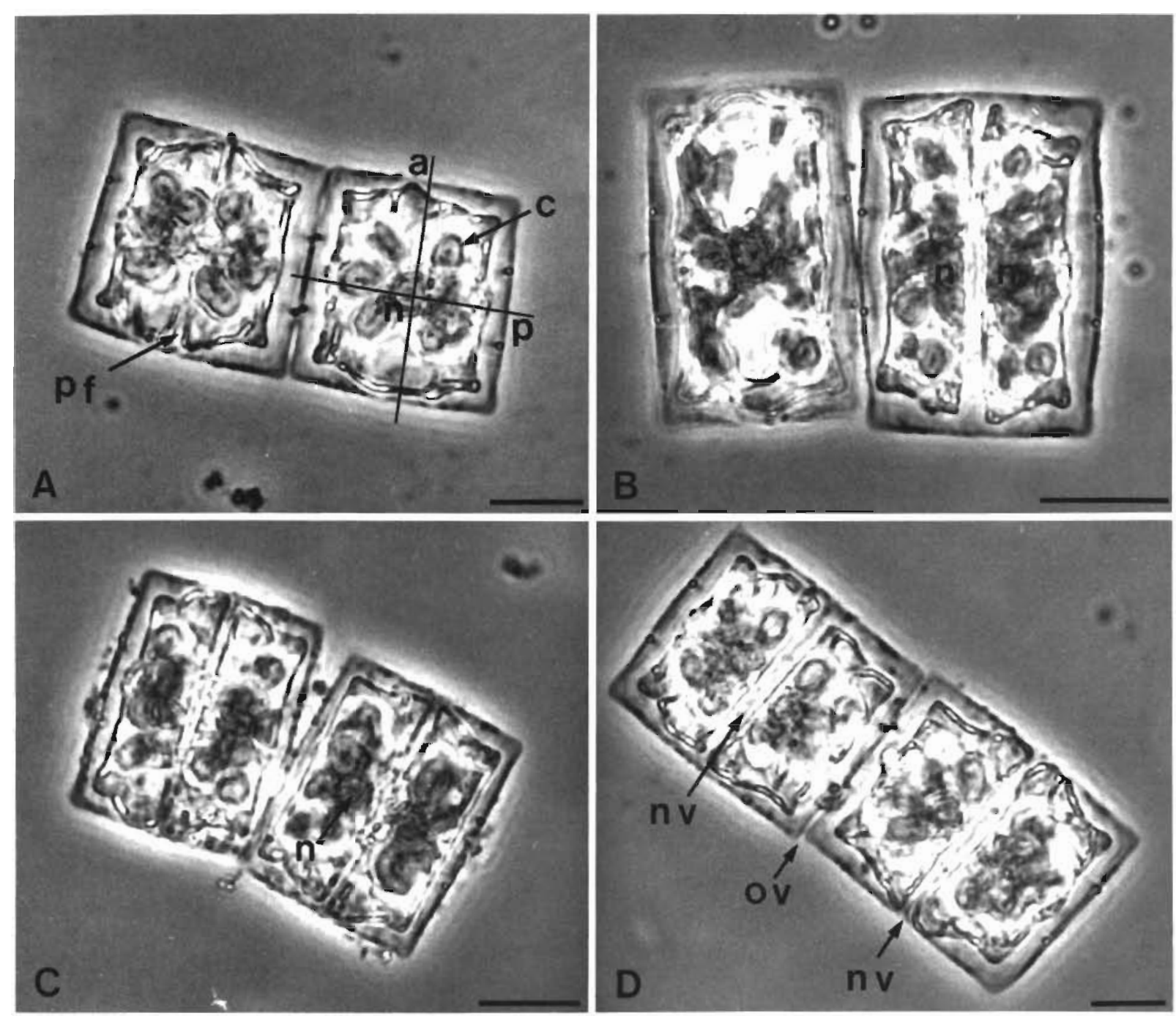

Fig. 1. Anaulus birostratus. Micrographs showing the sequence of anatomical changes common to field specimens undergoing asexual division. (A) Two cells in the initial stages of division, showing an enlargement of the pervalvar axis (p), polarization of the chromatophores (c) to either side of the undivided nucleus (n) and some evidence of protoplast fission (pf). The apical axis is denoted by (a). (B) Caryokinesis has taken place in the right hand cell and the 2 new daughter protoplasts are clearly evident. Note a lack of dividing valve. (C) Four new daughter cells, showing the new nuclei (n) and haphazardly arranged chromatophores. (D) Four recently divided cells, showing a clear distinction in the form of the newly developed dividing valves (nv) and the dividing valve formed during a previous division (ov). Scale: horizontal bars represent $10 \mu \mathrm{m}$

\section{RESULTS}

\section{Cell division}

From extensive preliminary work on Anaulus birostratus we have recognized a set pattern of events leading to the formation of daughter cells. The first signs are a widening of the pervalvar axis, followed by a rearrangement of the chromatophores, from an apparently haphazard distribution to one where they are aligned on 2 sides of the nucleus, along the pervalvar axis (Fig. 1A). At this stage there is also a change in the arrangement of the protoplast in preserved cells. Normally retracted from the frustule, the protoplast remains fully extended in the region of the girdle band (Fig. 1A). This is followed by some evidence of protoplast division (Fig. 1A) and later to 2 daughter protoplasts, both contained within the parental valves (Fig. $1 \mathrm{~B}$ ). There is a time lag, usually in excess of $1 \mathrm{~h}$, before valve morphogenesis becomes apparent (Fig. 1C). The above set of events has permitted us to select 3 criteria which had to be exhibited by the cells in order to be considered in the process of division. These characteristics, easily observed by routine light microscopy, were; (i) a change from the apparently haphazard arrangement of chromatophores to a distinct polarization, (ii) some evidence of protoplast division and (iii) the absence of dividing valves. The clear distinction 
between established, separated valves and recently formed valves (Fig. 1D) enabled us to distinguish between recently divided cells and older cells.

\section{Diel changes}

In Fig. 2, $3 \& 4$ the $24 \mathrm{~h}$ day is broken down into dawn, daylight, dusk and night. Dawn, here, is taken as the period between the first indication of a glow on the eastern horizon and sunrise. In April measurable levels of PPFD were first recorded $40 \mathrm{~min}$ after the beginning of dawn. Dusk was similarly recognized as the period between sunset and the last appearance of light on the western horizon.
The temporal profiles of Anaulus birostratus cell concentration in the inner surfzone during both the January and April exercises (Fig. 2) suggested a clear diurnal pattern. Cell concentration increased during the early morning and reached a maximum in early- to mid-afternoon. In January, all cells disappeared during the $3 \mathrm{~h}$ interval between the $1600 \mathrm{~h}$ and the $1900 \mathrm{~h}$ sampling sessions. During the night (until after $0300 \mathrm{~h}$ ) cell concentrations were below the detectable limit of 1 cell per $2 \mathrm{ml}$ sample.

Maximum division frequency $\left(\mathrm{F}_{\max }\right)$ occurred in the early morning hours (Fig. 3). Cell division frequency decreased in the afternoon, ceasing completely just before dusk. Division was recorded only an hour before dawn. The magnitude and timing of $F_{\max }$ varied little
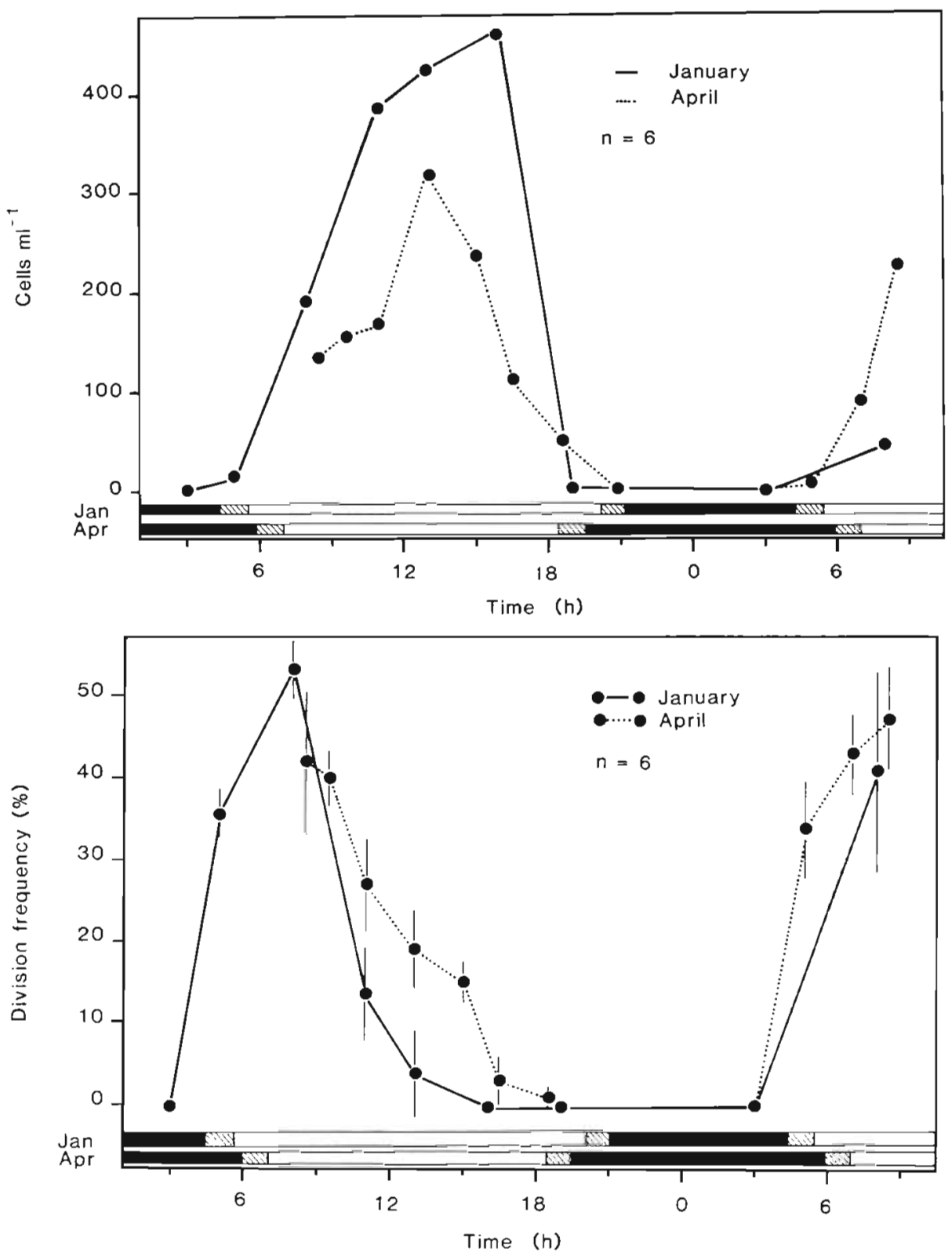

Fig. 2. Anaulus birostratus. Diel variation in cell concentration. Black bars: night; striped bars: dawn and dusk
Fig. 3. Anaulus birostratus. Diel variation in division frequency. Black bars: night; striped bars: dawn and disk. Vertical bars: SD 
Fig. 4. Anaulus birostratus. Diel variation in recently divided cells in April. Black bars: night; striped bars: dusk and dawn. Vertical bars: $\mathrm{SD}$

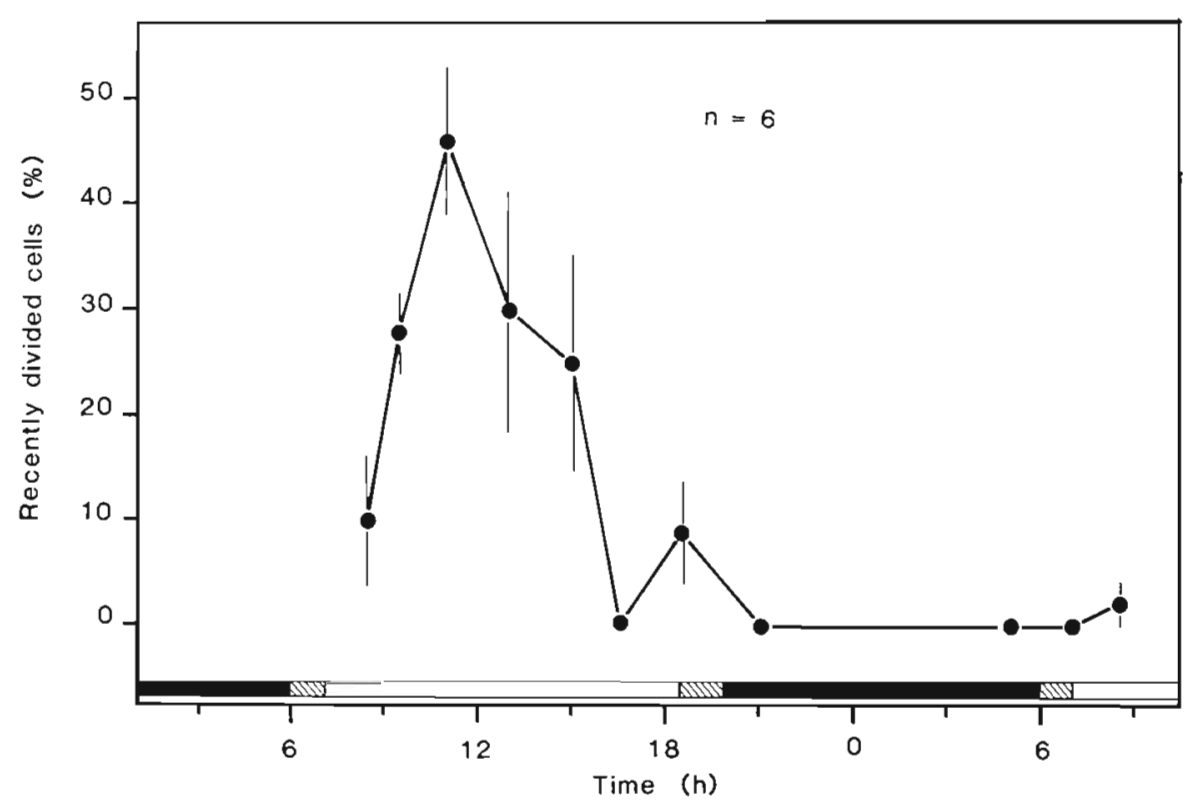

between January and April. Of interest is that in April particularly, division frequency was greater than $30 \%$ at least $1.5 \mathrm{~h}$ before dawn.

A least squares linear regression of cell concentration in the surfzone water and cell division frequency was not significant $\left(r^{2}=0.123, P>0.1\right)$. The regression was improved, however, when the concentration data were lagged by $3 \mathrm{~h}\left(\mathrm{r}^{2}=0.723, \mathrm{P}<0.001\right)$.

Specific growth rates were calculated both from the pattern of cell division $\left(\mu_{1}\right)$ and from the observed increase in cell number $\left(\mu_{2}\right)$, using the following equations:

$$
\begin{gathered}
\mu_{2}=1 / n t_{d}\left(1+F_{m a x}\right)(\text { McDuff \& Chisolm 1982) } \\
\mu_{2}=1 / t \operatorname{n}\left(N_{t} / N_{0}\right) \text { (Weiler \& Eppley 1979) }
\end{gathered}
$$

where $\mathrm{n}=$ number of samples; $\mathrm{t}_{\mathrm{d}}=$ duration of mitosis; $N_{t}=$ maximum population size $\mathrm{N}_{0}=$ population size at the beginning of the growth phase; $\mu=$ specific growth rate $\left(\mathrm{d}^{-1}\right) ; \mathrm{t}=$ time interval (in this case $1 \mathrm{~d}$ ). $t_{d}$ was taken as $3.5 \mathrm{~h}$, this being the time difference between $F_{\max }$ and the maximum frequency of recently divided cells in April (Fig. 4). It was assumed that this value was also applicable for the January data. Table 2 compares the specific growth rates $\mu_{1}$ and $\mu_{2}$. Cell division accounted for $13 \%$ of the observed increase in cell numbers in January, increas- ing to $21 \%$ in April. The distribution of recently divided cells measured in April 1985 (Fig. 4) was synchronized with the changes in cell concentration during the day (see Fig. 2).

Changes in the condition of the frustule during the 2 exercises (Fig. 5) also show a diel pattern. During periods of division, all cells investigated were found to be smooth-walled. During the post-division phase (early to late afternoon) $39 \%$ of the cells had a distinctly irregular margin. In January, $32 \%$ of cells had no recognizable frustule outline by $1900 \mathrm{~h}$. Evidence from light microscopic work indicates that instead of a change in the frustule itself, the change in cell appearance may, rather, be the result of adherence to the cell of unidentified foreign particles. Scanning and electron microscope studies are currently being undertaken to determine whether the growth of an outer organic layer is involved, as has been observed in Chaetoceros armatum (Lewin et al. 1979, 1980).

A temporal variation in cell dimensions was recorded in April (Fig. 6). There was no significant difference (Student t-test) in the average cell length $(\mathrm{P}>0.05)$, remaining between 23 and $27 \mu \mathrm{m}$ throughout the sampling period. In contrast, there was a marked change in the average width, increasing from $11 \mu \mathrm{m}$ at $0300 \mathrm{~h}$ to $18 \mu \mathrm{m}$ at $0830 \mathrm{~h}$. This was followed

Table 2. Anaulus birostratus. Comparison of specific growth rate calculated from the pattern of cell division $\left(\mu_{1}\right)$ with that

\begin{tabular}{|c|c|c|c|}
\hline Month & $\begin{array}{c}\mu_{1} \\
\left(\mathrm{~d}^{-1}\right)\end{array}$ & $\begin{array}{c}\mu_{2} \\
\left(\mathrm{~d}^{-1}\right)\end{array}$ & $\mu_{1} / \mu_{2}$ \\
\hline Jan & 0.73 & 5.74 & 0.13 \\
\hline Apr & 0.90 & 4.38 & 0.21 \\
\hline
\end{tabular}
calculated from the observed increase in cell numbers $\left(\mu_{2}\right)$ 


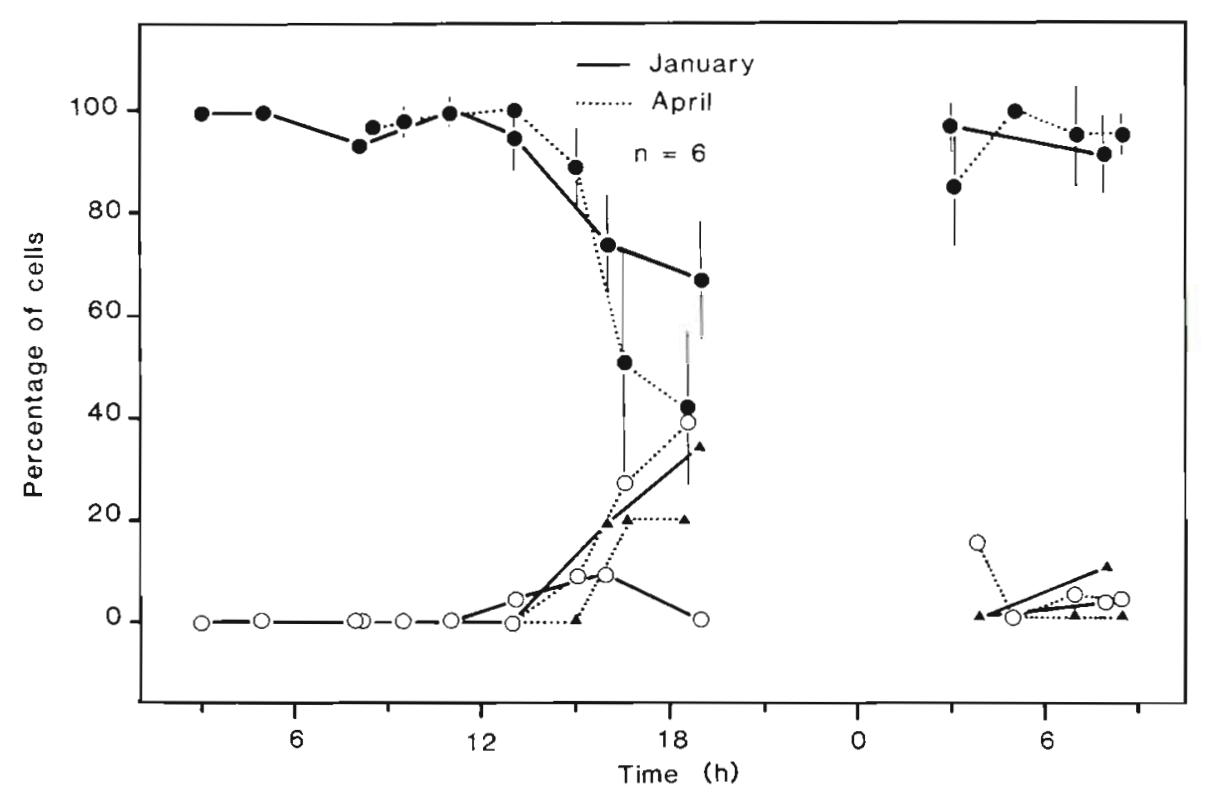

Fig. 5. Anaulus birostratus. Diel changes in cell frustule condition. $(\bullet$ percentage of cells with a smooth-edged frustule; 10 ) percentage of cells with irregular frustule outlines; (4) percentage of cells with no distinguishable edge. Vertical bars (shown only for smoothedged cells for clarity): SD by a decrease during the rest of the day, reverting back to $12 \mu \mathrm{m}$ by $1830 \mathrm{~h}$. This cyclic change in cell width was in phase with the pattern of cell division.

\section{DISCUSSION}

The proper identification of 'resting', 'dividing' and 'recently divided' cells is essential to many ecological investigations. The use of cell counts in estimating phytoplankton biomass often raises the question of when to count an entity as 1 or 2 cells. This can only be resolved if the phase of asexual reproduction can be established. Further, the accuracy associated with the use of division pattern in estimating the specific growth rate of phytoplankton populations also depends on the interpretation of the term 'dividing'. Despite this importance, studies of phytoplankton cell division suffer from a lack of standardization amongst workers with respect to the definition of a dividing cell. The choice of criteria for cell division is speciesspecific and somewhat subjective. Weiler \& Eppley (1979) used the absence of a horn on the dinoflagellate genus Ceratium as one of the criteria for cell division. Lewin \& Rao (1975) considered C. armatum to be dividing if it contained 2 nuclei, but no dividing valve. In Anaulus birostratus we have recognized a suite of characteristics that is consistently exhibited by the

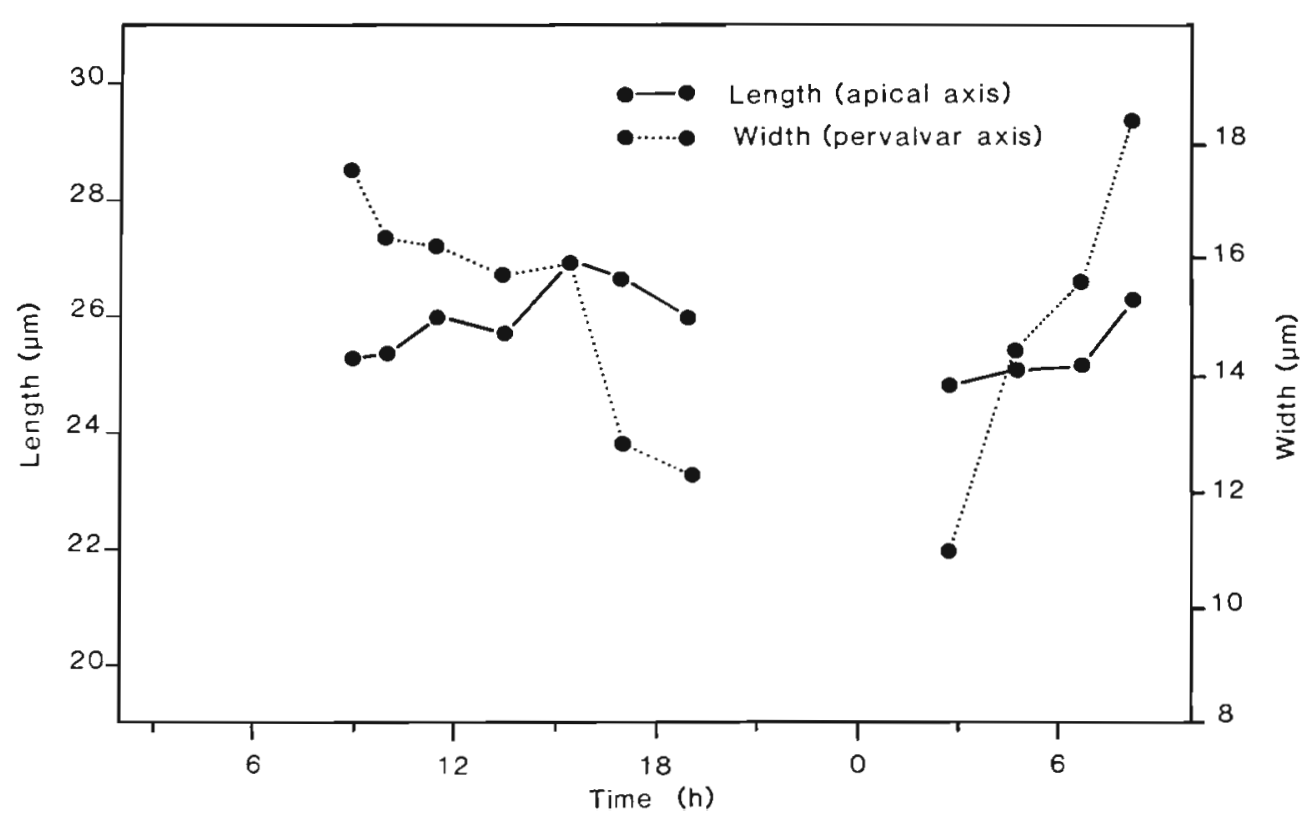

Fig. 6. Anaulus birostratus. Diel changes in dimensions 
dividing cell. These include the arrangement of chromatophores, clear evidence of protoplast fission and the absence of dividing valves.

The temporal profiles of cell concentration found here agree well with that reported by Sloff et al. (1984), showing a clear diel pattern with a diurnal peak. However, the sharp afternoon decreases resulted in complete disappearance of cells from the inner surfzone in these exercises, compared to the decrease to low numbers reported by Sloff et al. (1984).

The pattern of cell division is similar to that reported by Lewin \& Rao (1975) for the surf diatom Chaetoceros armatum in terms of the period of cell division and the maximum frequency of division achieved. The duration of division is here taken as the time interval during which the frequency of cell division is greater than half the maximum frequency, or $F=F_{\max } / 2$ (Weiler \& Eppley 1979). The computed values from data presented by Lewin \& Rao (1975) give a range of duration from 9 to $14.5 \mathrm{~h}$, longer than those for Anaulus birostratus ( $6.5 \mathrm{~h}$ in January to $9 \mathrm{~h}$ in April). Weiler \& Eppley (1979) reported values of 8 to $16 \mathrm{~h}$ for laboratory cultures of the genus Ceratium and 3.5 to $7.5 \mathrm{~h}$ for natural populations of the same taxon. A further difference between the 2 surf diatoms is a maintenance of division activity, albeit low (7 to $14 \%$ ), in C. armatum during the night in contrast to a lack of evidence of activity in $A$. birostratus.

The restriction of division in Anaulus birostratus to the early morning hours agrees closely with that of Chaeotoceros armatum and for several species of Ornithocerus Stein (Weiler \& Eppley 1979). Williamson (1980) presented a short review of the major factors that have been proposed as a cue for the initiation of cell division. These include photoperiod, temperature, nutrients, tidal cycle and selective grazing. Light per se is rejected as a direct cue for the initiation of division in A. birostratus. Lewin \& Rao (1975) emphasized that division in $C$. armatum occurs even while stars are still visible. We have accurately recorded light events during the early pre-sunrise periods and found division not only prior to any measurable levels of PPRD, but also before dawn. Despite a difference in the temperature and tidal cycle between the January and April exercises we found no change in the timing of cell division. These 2 factors are therefore also rejected as possible cues.

Grazing may play an important role. Williamson (1980) described the general pattern of nocturnal vertical migration of oceanic copepods to the epilimnion. This, he argued, resulted in a selective pressure for a division pattern peaking outside the night period. An analogous situation occurs in the surf ecosystem in Algoa Bay where, instead of a vertical migration, a clear pattern of onshore-offshore migration of various grazers has been reported. Wooldridge (1983) observed at our study site that during the late afternoon the mysid shrimp Mesopodopis slabberi van Beneden migrates from the offshore to immediately behind the breaker line. They depart from the region by $0500 \mathrm{~h}$ the following morning. Also working at this site, Cockroft (1983) reported a distinct nocturnal increase in the population size of the swimming shrimp Macropetasma africanum (Balss). Although much more work is needed on the grazing pressure on the diatoms by these organisms it is plausible that the strict phasing of cell division to after $0500 \mathrm{~h}$ represents an adaptation which minimizes mortality. This would provide some support for the argument of Williamson (1980).

The surfzone at the Sundays River Beach appears to be partially dominated by rip currents (Talbot \& Bate unpubl.), involving a strong onshore-offshore flow component. It is therefore possible that the division pattern is an artefact of the hydrodynamics and cell density. Cells in different stages of asexual reproduction, through their different densities, could undergo differential onshore-offshore movement, thereby creating the observed pattern in cell division.

The percentage of recently divided cells maximized approximately $3.5 \mathrm{~h}$ after the initiation of cell division, by which time the cells were photosynthetically active. Having observed the pattern of diurnal division in 13 species of marine phytoplankton. Nelson \& Brand (1979) hypothesised that diatoms cannot divide at night since cells are incapable of storing enough energy for both cell division and silicic acid uptake. If so, Anaulus birostratus overcomes this by dividing at night and retarding valve formation until the cells are at peak photosynthetic activity. Although light is not the cue for initiation of cell division, the whole sequence of asexual reproduction is, in a more complex manner, linked to the light/dark cycle.

We need to consider whether the diurnal patches of high cell density of Anaulus birostratus are indeed blooms. A comparison of the diel pattern of cell numbers and cell division indicated close synchrony between them. The large increase in cell number at approximately $1000 \mathrm{~h}$ followed by $3 \mathrm{~h}$ the increase in cell division rate and coincided accurately with the appearance of recently divided cells. Quantitatively, however, we found that the specific growth rate through cell division accounted, at best, for only $21 \%$ of the observed increase in cell numbers. It appears, therefore, that while linked to the diel periodicity in cell concentration, division in the inner surfzone was inadequate to account for the observed increases in cell numbers. A large influx of cells must therefore take place during the morning.

A. $52 \%$ increase in cell size accompanied the onset of 
cell division. We suggest that, without a corresponding increase in mass, the resultant decrease in density rendered the cells more susceptible to vertical turbulence, thereby increasing their mobility and ultimately their transportation into the inner surfzone. In addition to density, both cell shape (Stoke's Law) and cell size (Smayda 1970, Olivieri 1983) could account for a buoyancy change. The large cell influx concerned here is different from the 'seeding' process suggested by Winter (1983). In the afternoon, the removal of cells from the inner surfzone must coincide with an increased sinking rate, either through an increase in the density of the organism or a loss of its floatation ability. Rapid cell removal from the growing area has often been reported for marine diatoms (Akinina 1969, Wiseman et al. 1983, Smetacek 1985).

The selective value of cell removal from nutrientdepleted areas during the non-growing stage of bloom diatoms can be appreciated in open systems. Within the inner surfzone, however, particularly at the Sundays River Beach where the water mass is effectively flushed by rip current activity, some factor other than nutrient depletion must lead to cell removal. McLachlan \& Lewin (1981) suggested that cell removal from the inner surfzone is a response to increased nocturnal grazing pressure within the breaker zone. This view is not consistent with the fact that the mysid Mesopodopsis slabberi feeds nocturnally in large swarms behind the breaker zone. However because of the deeper water, a movement of Anaulus birostratus from the inner surfzone to areas seaward of the breaker line would sharply reduce the cell concentration through a dilution effect, thereby reducing grazing efficiency.

We propose the following hypothesis to explain the appearance and disappearance of cells within the inner surfzone. Changes in cell shape, size and/or density that occur upon cell division render them more susceptible to turbulence and govern the exchange of cells between their nocturnal habitat and the water column of the inner surfzone during the day. Cells are driven shoreward by the mass transport generated by breaking waves. Once in the inner surfzone, the cells are filtered out of the water column by air bubbles entrained by passing wave bores (mechanism unknown), are concentrated at the air/water interface and consequently retained within the surfzone by the onshore shear stress of wave bores. Cells would lose their floatation mechanism in the late afternoon, become redistributed throughout the water column and be removed from the inner surfzone by the offshore advection of rip currents. This hypothesis is analogous to that presented by Akinina (1969) to explain the diurnal increase in phytoplankton numbers in the euphotic zone. Instead of a lateral transport as suggested here, he argued that cells in open waters undergo a vertical migration upon division, so that the early morning increase in cell numbers is both a result of cell division and changes in the settling rate.

Coupled to the afternoon decrease in cell numbers is a change in the outer appearance of the frustules. The exact significance of this, in the context of patch dynamics, is not clear. Cytological studies of the cell surface at the electron microscope are needed in order to identify the exact nature of this change and to determine whether such alterations play a role in the disappearance of cells from the inner surfzone.

The close synchrony between cell dimensions and cell division frequency confirms the well-reported process of cell enlargement (broadening) during cell division (Smayda \& Boleyn 1965, Hammer \& Brockman 1983) and confirms our grouping of cells into the 3 classes: (i) resting, (ii) dividing and (iii) recently divided.

Both the January and April experiments were carried out during calm conditions, when the intensity of Anaulus birostratus patches only reached $10 \%$ of the maximum ever observed. Although these conditions are close to the modal state at the Sundays River Beach, the validity of the conclusions drawn here may be restricted. The patterns of diel changes described in this report could conceivably be different during high energy conditions that coincide with high $A$. birostratus cell concentrations.

\section{CONCLUSION}

Anaulus birostratus is characterized by a diel periodicity in asexual reproduction. This periodicity could account for the large diel pattern in cell numbers in 2 ways: (a) directly, by cell recruitment through division, and (b) more importantly, by increasing the exchange of cells between the surfzone and, presumably, adjacent zones.

The similarity of behavioural characteristics between Anaulus birostratus and Chaetoceros armatum, 2 of the major species of surfzone diatoms, suggests the above sequence as being common to this class of diatoms.

Acknowledgements. We thank Professor A. McLachlan for his support and helpful comments during all phases of this study. Dr. T. Donn and Mrs V. Talbot are thanked for their help in the field. The work was funded by the South African National Committee for Oceanographic Research.

\section{LITERATURE CITED}

Akinina, D. K. (1969). Relative settling rate of dinoflagellata in relation to their rates of division. Oceanology 9: 248-251 
Anderson, D. M., Chisolm, S. W., Watras, C. J. (1983). Importance of life cycle events in the population dynamics of Gonyaulux tamarensis Lebour. Mar. Biol. 76: 179-189

Anonymous (1975). Proposals for a standardization of diatom terminology and diagnoses. Hova Hedwigia, Beih. 53: 323-354

Campbell, E. E., Fock, H. P., Gate, G. C. (1985). Exudation of recently fixed photosynthetic products from surfzone phytoplankton of the Sundays River Beach. Botanica mar. 28: 399-405

Cassie, R. M., Cassie, V (1960). Primary production in a New Zealand west coast phytoplankton bloom. N. Z. Jl Sci. 3: 173-199

Cockcroft, A. C. (1983). Aspects of the biology of the swimming prawn Macropetasma africanus (Balss). M. Sc. thesis. Univ. of Port Elizabeth, South Africa

Drebes, G., Schulz, D. (1981). Anaulus creticus sp. nov., a new centric diatom from the Mediterranean Sea. Bacillaria 4: $161-176$

Garver, J. L., Lewin, J. (1981). Persistent blooms of surf diatoms along the Pacific Coast. USA. I. Physical characteristics of the coastal region in relation to the distribution and abundance of the species. Estuar. coast. mar. Sci. 12: 217-229

Gunter, G., Lyles, C. H. (1979). Localized plankton blooms and jubilees on the Gulf Coast. Gulf Res. Rep. 6: 297-299

Hammer, K. D., Brockman, U. H. (1983). Rhythmic release of dissolved free amino acids from partly synchronised Thalassiosira rotula under nearly natural conditions. Mar. Biol. 74: 305-312

Hayes, M. O. (1979). Barrier island morphology as a function of tidal and wave regime. In: Leatherman, S. P. (ed.) Barrier Islands. Academic Press, New York, p. 1-27

Kindley, M. J. (1983). Physiological ecology of surfzone diatoms. M. Sc. dissertation, University of Auckland, New Zealand

Lewin, J., Hruby, T. (1973). Blooms of surf-zone diatoms along the coast of the Olympic Peninsula, Washington. II. A diel periodicity in buoyancy shown by the surf-zone diatom species, Chaetoceros armatum T. West. estuar. coast. mar. Sci. 1: 101-105

Lewin, J., Rao, V. N. R. (1975). Blooms of surf-zone diatoms along the coast of the Olympic Peninsula, Washington. VI. Daily periodicity phenomena associated with Chaetoceros armatum $\mathrm{T}$. West in its natural habitat. J. Phycol. 11: 330-338

Lewin, J., Chen, C., Hruby, T. (1979). Blooms of surfzone diatoms along the coast of the Olympic Peninsula. Washington. $X$. Chemical composition of the surfzone diatom Chaetoceros armatum and its major herbivore, the Pacific razor-clam, Siligua patula. Mar. Biol. 51: 259-265

Lewin, J., Colvin, J. R., McDonald, K. L. (1980). Blooms of surf-zone diatoms along the Olympic Peninsula Washington. XII. The clay coat of Chaetoceros armatum T. West. Botanica mar. 23: 333-341

McDuff, R. E., Chisolm, S. W. (1982). The calculation of in situ growth rates of phytoplankton populations from fractions of cells undergoing mitosis: A clarification. Limnol. Oceanogr. 27: 783-788

McLachlan, A., Lewin, J. (1981). Observations on surf phytoplankton blooms along the coasts of South Africa. Botanica mar. 24: 553-557
McLachlan, A., Cockroft, A. C., Malan, D. E. (1984). Benthic faunal response to a high energy gradient. Mar. Ecol. Prog. Ser 16: 51-63

Nelson, D. M., Brand, L. E. (1979). Cell division periodicity in 13 species of marine phytoplankton on a light:dark cycle. J. Phycol. 15: 67-75

Olivieri, E. T. (1983). Colonization, adaptations and temporal changes in density and biomass of a phytoplankton community in upwelled water of the Cape Peninsula, South Africa, in December 1979. S. Afr. J. mar. Sci. 1: 77-109

Saraceni, C., Ruggiu, D. (1974). Techniques for sampling water and phytoplankton. In: Vollenwider, R. A. (ed.). A manual on methods for measuring primary production in aquatic environments (2nd edn). IBP handbook No. 12. Blackwell Scientific Publications, Oxford, p. 5-7

Sloff, D. S. (1984). Spatio-temporal biomass distribution of surf zone phytoplankton. M. Sc. thesis. University of Port Elizabeth, South Africa

Sloff, D. S., McLachlan, A., Bate, G. C. (1984). Spatial distribution and diel periodicity of Anaulus birostratus Grunow in the surf zone of a sandy beach in Algoa Bay, South Africa. Botanica mar. 27: 461-465

Smayda, T. J. (1970). The suspension and sinking of phytoplankton in the sea. Oceanogr. mar Biol. A. Rev. 8: 353-414

Smayda, T. J., Boleyn, B. J. (1965). Experimental observations on the flotation marine diatoms. I. Thalassiosira cf. nana, Thalassiosira rotula and Nitzschia seriata. Limnol. Oceanogr. 10: 499-509

Smetacek, V. S. (1985). Role of sinking in diatom life-history cycles: ecological, evolutionary and geological significance. Mar. Biol. 84: 239-251

Sournia, A. (1974). Circadian periodicities in natural populations of phytoplankton. Adv. mar. Biol. 12: 325-389

Utermöhl, H. (1958). Zur Vervollkommnung der quantitativen Phytoplankton Methodik. Mitt. int. Verein. theor. angew. Limnol. 9: 1-38

Weiler, C. S., Eppley, R. W. (1979). Temporal pattern of division in the dinoflagellate genus Ceratium and its application to the determination of growth rates. J. exp. mar. Biol. Ecol. 39: 1-24

Williamson, C. E. (1980). Phased cell division in natural and laboratory populations of marine planktonic diatoms. J. exp. mar. Biol. Ecol. 43: 271-279

Winter, D. F. (1983). Theoterical model of surf zone circulation and diatom growth. In: McLachlan, A., Erasmus, T. (ed.) Sandy beaches as ecosystems. Dr. W. Junk Publishers, The Hague, p. 157-168

Wiseman, S. W., Jaworski, G. H. M., Reynolds, C. S. (1983). Variability in sinking rate of the freshwater diatom Asterionella formosa Hass.: The influence of excess density of colonies. Br. phycol. J. 18: 425-432

Wooldridge, T. H. (1983). Ecology of beach and surf-zone mysid shrimps in the eastern Cape, South Africa. In: McLachlan, A., Erasmus, T. (ed.) Sandy beaches as ecosystems. Dr. W. Junk Publishers, The Hague, p. 449-460

Wright, L. D., Short, A. D. (1983). Morphodynamics of beaches and surfzones in Australia. In: Komar, P. D. (ed.) CRC Handbook of coastal processes and erosion, CRC Press, Boca Raton, p. 3564 